\title{
Comparison between liver and serum concentrations of mannan binding protein
}

\author{
N G Ryley, A R Heryet, J Lu, K B M Reid, K A Fleming
}

\begin{abstract}
Aims: To investigate staining patterns for mannan binding protein (MBP) by immunocytochemistry in liver biopsy specimens from patients with various hepatic disorders; to measure the serum MBP concentration in the patients at the time of biopsy; and to compare these to define further the role of MBP in disease. Methods: Fifty seven consecutive patients with a variety of types of liver disease were studied. Fresh liver biopsy specimens were immunostained with antiMBP and graded for intensity of staining. Serum MBP concentrations were measured on samples obtained on the day of biopsy, as were a full range of liver blood tests.

Results: MBP was only detectable in liver biopsy specimens from patients with morphological evidence of liver disease. MBP was most prominent in the livers of patients with severe alcoholic liver disease; livers harbouring metastases or showing biliary disease had moderate concentrations. Patients with liver disease were more likely to have raised serum MBP concentrations, but there was no correlation between these values and those found in the biopsy specimens. There was also no significant correlation between either of these concentrations and liver blood test abnormalities.

Conclusions: Patients with liver disease tend to have raised MBP concentrations in both the liver and serum, but the exact relation between the two is as yet undefined.
\end{abstract}

(f Clin Pathol 1993;46:259-263)

Mannan binding protein (MBP) was first

Table 1 MBP in patients with normal liver biopsy specimens

\begin{tabular}{lllllllll}
\hline $\begin{array}{l}\text { Case } \\
\text { No }\end{array}$ & $\begin{array}{l}\text { Liver biopsy specimen } \\
\text { appearance }\end{array}$ & $\begin{array}{l}\text { Serum } \\
(\mu \mathrm{g} / \mathrm{l})\end{array}$ & $\begin{array}{l}\text { Missue } \\
\text { MBP }\end{array}$ & AST & AP & GGT & Albumin & Bilirubin \\
\hline 1 & Normal & 1207 & 0 & 47 & 373 & 114 & 46 & 9 \\
2 & Normal & 4532 & $0 / 1$ & 25 & 220 & 9 & 50 & 5 \\
3 & Normal & 292 & 0 & 34 & 198 & 75 & 55 & 10 \\
\hline
\end{tabular}

Tissue MBP expressed as strength of staining of liver biopsy specimens with anti-MBP on a scale 0-3.

AST = aspartate aminotransferase, normal range 10-35 IU/

$\mathrm{AP}=$ alkaline phosphatase, normal range $100-300 \mathrm{IU} / 1$

GGT = gamma glutamyl transpeptidase, normal range 15-35 IU/1

Albumin: normal range $35-50 \mathrm{mmol} / \mathrm{I}$

Bilirubin: normal range 3-17 $\mu \mathrm{mol} / 1$ described in 1978 in rabbit liver, ${ }^{1}$ since when it has been isolated from the liver and serum of humans and a wide range of animals. ${ }^{2-5}$

It is a $\mathrm{Ca}^{2+}$ dependent lectin which structurally resembles the complement component C1q. It can bind to the cell walls of microorganisms including Gram negative bacteria, mycobacteria, and yeasts. It is thought to perform several functions, including acting as a focus for complement activation on the surface of micro-organisms, ${ }^{6}$ acting as an opsonin in defence against some microorganisms, ${ }^{7}$ preventing infection of $\mathrm{H} 9$ lymphoblasts by HIV in vitro, ${ }^{8}$ and it may also behave as an acute phase reactant. ${ }^{9}$ MBP deficiency has been reported to result in recurrent severe infections in some children. ${ }^{6}$

A previous study investigating immunohistochemical staining for MBP in human tissues, ${ }^{10}$ in which a wide range of tissues from three post mortem cases and 71 liver biopsy specimens were studied, showed that the liver was the only tissue to contain clinically important amounts of MBP. An interesting finding was that morphologically normal liver contained virtually no stainable MBP (seven biopsy and three post mortem cases); liver tissue from patients with a range of hepatic diseases showed a variable degree of positive staining. The most noticeable staining was seen in patients with severe alcoholic liver disease (cirrhosis) and those with metastatic tumours in the liver, with moderate staining seen in patients with biliary disease.

There is a wide range for the normal serum concentration of MBP, with $90 \%$ of values lying between 33 and $2656 \mu \mathrm{g} / 1$ (these values having now been revised by a factor of 16.6 from those originally quoted. $)^{11}$ As there are also wide variations in the concentrations of MBP in the liver, as detected by immunohistochemistry, ${ }^{10}$ we designed a study to investigate serum MBP concentrations in a group of patients with liver disease, and compared these concentrations with the amount of MBP detected in the liver biopsy specimens taken at the same time as the serum samples.

\section{Methods}

The patient group tested consisted of 57 patients undergoing liver biopsy in Oxford over an eight month period from whom fresh frozen tissue was available. The average age of the patients was 46 (range 13-78 years), the sex ratio was 1:1.4 (women:men). The racial origin of most of the patients was Caucasian. 
Table 2 MBP in patients with alcoholic liver disease

\begin{tabular}{llllrrrrr}
\hline $\begin{array}{l}\text { Case } \\
\text { No }\end{array}$ & $\begin{array}{l}\text { Liver biopsy specimen } \\
\text { appearance }\end{array}$ & $\begin{array}{l}\text { Serum } \\
(\mu g / l)\end{array}$ & $\begin{array}{l}\text { Tissue } \\
\text { MBP }\end{array}$ & AST & AP & GGT & Albumin & Bilirubin \\
\hline 4 & Fatty change & 2832 & $0 / 1$ & 44 & 266 & 257 & 49 & 11 \\
5 & Fatty change & 1888 & 1 & 53 & 266 & 134 & 44 & 13 \\
6 & Fatty change & 1771 & 1 & 46 & 376 & 413 & 44 & 8 \\
7 & Fatty change & 2266 & 1 & 20 & 91 & 11 & 44 & 8 \\
8 & Fatty change & 1814 & 2 & 69 & 288 & 679 & 45 & 7 \\
9 & Hepatitis & 2546 & 1 & 95 & 181 & 37 & 50 & 7 \\
10 & Hepaatitis & 6122 & $1 / 2$ & 67 & 336 & 113 & 29 & 17 \\
11 & Hepatitis & 3407 & $1 / 2$ & 55 & 182 & & 49 & 4 \\
12 & Fatty + fibrosis & 98 & 2 & 72 & 378 & 146 & 42 & 15 \\
13 & Fibrosis & 125 & 2 & 25 & 499 & 79 & 31 & 10 \\
14 & Hepatitis + fibrosis & 17306 & $1 / 2$ & 29 & 176 & 79 & 44 & 9 \\
15 & Hepatitis + fibrosis & 13197 & 2 & 113 & 486 & 778 & 44 & 35 \\
16 & Hepatitis + fibrosis & 1954 & 2 & 113 & 420 & 273 & 33 & 9 \\
17 & Hepatitis + fibrosis & 4532 & 2 & 262 & 826 & 2861 & 28 & 184 \\
18 & Hepatitis + fibrosis & 3021 & $2 / 3$ & 72 & 252 & 240 & 29 & 18 \\
19 & Hepatitis + fibrosis & 926 & 3 & 82 & 206 & 293 & 47 & 13 \\
20 & Severe fibrosis & 2201 & $2 / 3$ & 25 & 225 & 295 & 27 & 6 \\
21 & Cirrhosis & 604 & 2 & 118 & 388 & 73 & 29 & 478 \\
22 & Cirrhosis & 7558 & 2 & 121 & 753 & & 30 & 79 \\
23 & Cirrhosis & 354 & 3 & 60 & 541 & 243 & 37 & 6 \\
24 & Cirrhosis + hepatitis & 544 & 3 & 96 & 399 & 218 & 43 & 20 \\
25 & Cirrhosis + hepatitis & 493 & 3 & 68 & 235 & 559 & 42 & 15 \\
26 & Cirrhosis + hepatitis & 769 & 3 & 134 & 336 & 124 & 23 & 52
\end{tabular}

Tissue MBP is strength of staining of liver biopsy specimens with anti-MBP on a scale $0-3$. See table 1 for normal ranges of liver blood tests.

About $0.5-1.0 \mathrm{~cm}$ of fresh tissue from each biopsy specimen was snap frozen and stored in liquid nitrogen within 30 minutes of the procedure, as part of our routine protocol with liver biopsy specimens. The rest of the tissue was processed routinely (paraffin wax sections) for diagnostic purposes. Frozen sections $(5 \mu \mathrm{m})$ were cut on to gelatine-chrome alum coated multispot slides, and air dried for 2-18 hours. Fixation consisted of acetone for 10 minutes at room temperature.

Serum samples, which had been stored at $4^{\circ} \mathrm{C}$, were retrieved from the blood transfusion department (such samples are routinely taken for all patients undergoing biopsy), before being frozen down to $-70^{\circ} \mathrm{C}$ and stored prior to analysis in batches.

The antibody used was the IgG fraction $(1.1 \mathrm{mg} / \mathrm{ml}$ in $70 \mathrm{mM}$ phosphate buffer at $\mathrm{pH}$ $7 \cdot 4$ ) of rabbit anti-human mannan binding protein, prepared as described previously. ${ }^{11}$

Staining was carried out by the indirect immunoperoxidase technique using standard protocols, as described in our previous study. ${ }^{10}$ Two negative controls (no primary antibody; rabbit anti-human chorionic gonadotrophin (Dako) diluted 1 in 200 as primary antibody) were included on each slide. A known positive case from the previous study was included as a positive control with all the batches of slides stained.

Grading of staining density was assessed on a scale of $0-3$, grade 3 being defined as the most intense degree of staining (strong cyto-

Table 3 MBP in patients with metastatic malignant tumours

\begin{tabular}{|c|c|c|c|c|c|c|c|c|}
\hline $\begin{array}{l}\text { Case } \\
\mathrm{No}\end{array}$ & $\begin{array}{l}\text { Liver biopsy specimen } \\
\text { appearance }\end{array}$ & $\underset{(\mu g / l)}{\text { Serum }} M B P$ & $\begin{array}{l}\text { Tissue } \\
M B P\end{array}$ & $A S T$ & $A P$ & $G G T$ & Albumin & Bilirubin \\
\hline $\begin{array}{l}27 \\
28 \\
29 \\
30\end{array}$ & $\begin{array}{l}\text { Metastasis } \\
\text { Metastasis (not in bx) } \\
\text { Metastasis } \\
\text { Metastasis }\end{array}$ & $\begin{array}{r}755 \\
4235 \\
4804 \\
795\end{array}$ & $\begin{array}{l}1 \\
1 \\
2 \\
3\end{array}$ & $\begin{array}{r}100 \\
318 \\
695 \\
64\end{array}$ & $\begin{array}{r}574 \\
596 \\
1874 \\
733\end{array}$ & $\begin{array}{l}715 \\
\overline{861} \\
149\end{array}$ & $\begin{array}{l}47 \\
34 \\
35 \\
30\end{array}$ & $\begin{array}{r}9 \\
84 \\
145 \\
8\end{array}$ \\
\hline
\end{tabular}

Tissue MBP is strength of staining of liver biopsy specimens with anti-MBP on a scale 0-3. See table 1 for normal ranges of liver blood tests.

Cases 27 and 29 represented metastatic neuroendocrine tumours; case 30 was a metastatic adenocarcinoma (origin from large bowel); case 28 was a case of metastatic pancreatic adenocarcinoma, which was present in the formalin fixed specimen but not in the fresh portion (bx) used in this study. plasmic stain) found within this sample. Direct comparisons were made between anti$\mathrm{MBP}$ at 1 in 50 and the hcG control present on each multispot slide.

Microtitre plates (Nunc-Immuno plate, GibCo) were coated at room temperature with rabbit anti-human MBP IgG (100 $\mu \mathrm{l}$ per well of a $10 \mathrm{mg} / \mathrm{ml}$ solution) in $15 \mathrm{mM}$ $\mathrm{Na}_{2} \mathrm{CO}_{3}, 35 \mathrm{mM} \mathrm{NaHCO}$, (pH 9.6) for 16 hours and then washed three times with TBS-NTBSA (50 mM TRIS- $\mathrm{HCl}, 150 \mathrm{mM}$ $\mathrm{NaCl}, 0.05 \%$ (w/v) $\mathrm{NaN}_{3}, 0.05 \%$ (v/v) Tween-20 and $1 \mathrm{mg} / \mathrm{ml}$ bovine serum albumin, $\mathrm{pH} 7 \cdot 4$ ). Unbound sites were blocked with TBS-NTBSA for 2-3 hours at room temperature. After washing in the same buffer the plates were incubated with a 1 in 1000 dilution of mannan-biotin in TBS$\mathrm{NTCa}^{2+} \mathrm{BSA}\left(20 \mathrm{mM} \mathrm{CaCl}_{2}\right.$ in TBSNTBSA) or TBS-NTEBSA, thus providing calcium dependent and calcium independent binding values. The wells were washed with TBS-NTCa ${ }^{2+}$ BSA or TBS-NTEBSA and ExtrAvidin-alkaline phosphatase conjugate (Sigma E2636), diluted 1 in $10^{4}$ in TBS-NT $\mathrm{Ca}^{2+}$, was added followed by incubation overnight at $4^{\circ} \mathrm{C}$. The plates were then washed with TBS-NTCa ${ }^{2+} \mathrm{BSA}$ and a phosphatase substrate (p-nitrophenyl phosphate disodium; Sigma Chemicals) in $50 \mathrm{mM}$ TRIS-HCl, $5 \mathrm{mM} \mathrm{CaCl}, 5 \mathrm{mM} \mathrm{MgCl}_{2}$ and $0.05 \%(\mathrm{w} / \mathrm{v}) \mathrm{NaN}_{3}, \mathrm{pH} 9.5$, added to give a final concentration of substrate of $1 \mathrm{mg} / \mathrm{ml}$. The plates were read after about 30 minutes of incubation at $37^{\circ} \mathrm{C}$ on a MultiskanR MCC/340 (Titertek Co Ltd). The assay detected MBP down to a concentration of $1 \mathrm{ng} / \mathrm{ml}$ and was standardised by using a preparation of purified MBP, the concentration of which had been determined by amino acid analysis.

\section{Results}

The patients were split into six groups on the basis of their liver pathology. These groups were normal (table 1), alcoholic liver disease (table 2), metastatic disease (table 3), biliary disease (table 4), hepatitis (table 5) and miscellaneous (table 6).

Results are given in tables 1-6 for serum MBP, liver MBP, and the patients' liver blood tests performed on the day of the biopsy (aspartate aminotransferase (AST), alkaline phosphatase (AP), $\gamma$ glutamyl transpeptidase (GGT), albumin and bilirubin) for these six groups of patients.

Table 7 shows the correlation coefficients for the various potential associations: none was significant.

Table 8 shows the 17 patients with serum MBP results of more than $2656 \mu \mathrm{g} / \mathrm{l}$, arranged in ascending order with respect to the serum MBP; correlation coefficient $0 \cdot 268$.

The results expressed in tables 1-6 are summarised as follows:

Normal liver pathology: no significant staining with anti-MBP.

Alcoholic liver disease: virtually all cases showed MBP in the liver sections, with the 


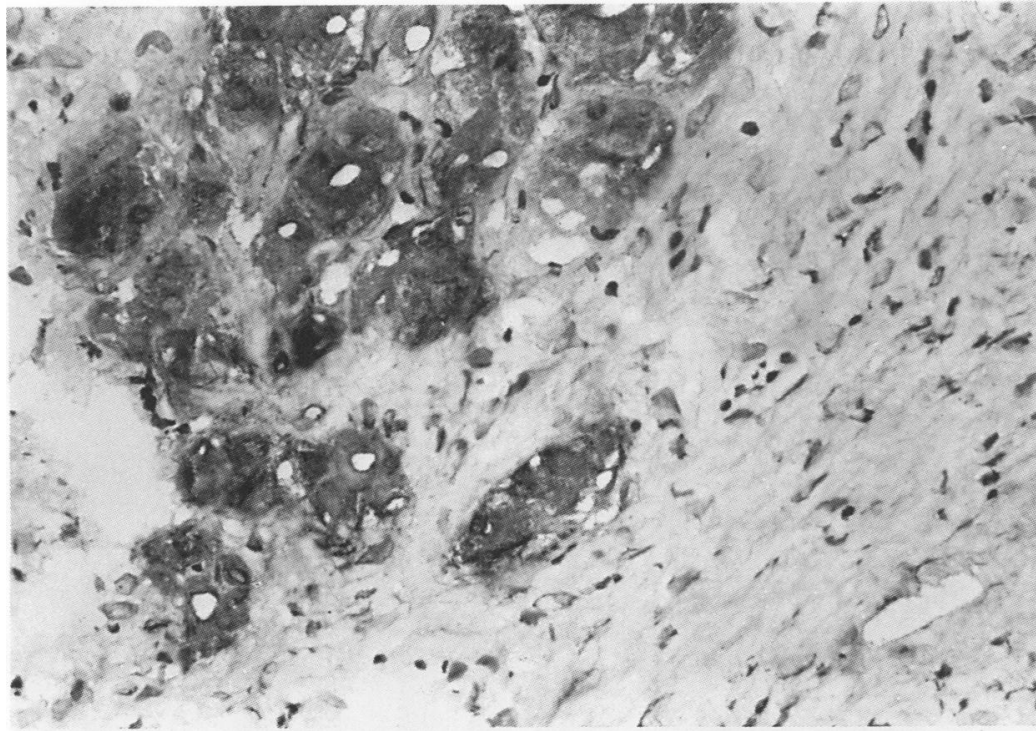

Figure 1 Liver biopsy specimen showing alcoholic cirrhosis. Strong (grade 3) immunoperoxidase staining of hepatocytes with anti-MBP on frozen tissue section.

\section{Table $4 \mathrm{MBP}$ in patients with biliary disease}

\begin{tabular}{lllllllll}
\hline $\begin{array}{l}\text { Case } \\
\text { No }\end{array}$ & $\begin{array}{l}\text { Liver biopsy specimen } \\
\text { appearance }\end{array}$ & $\begin{array}{l}\text { Serum } \\
(\mu \mathrm{g} / \mathrm{l})\end{array}$ & $\begin{array}{l}\text { Missue } \\
M B P\end{array}$ & AST & AP & GGT & Albumin & Bilirubin \\
\hline 31 & PSC stage 1 & 2160 & 1 & 189 & 1906 & 486 & 39 & 28 \\
32 & PSC & 71 & 2 & 26 & 420 & 151 & 47 & 7 \\
33 & PBC stage 2 & 10113 & 2 & 149 & 492 & 192 & 45 & 10 \\
34 & ldo & 1018 & 1 & 29 & 745 & 135 & 24 & 7 \\
35 & ldo & 1972 & 2 & 76 & 1241 & 763 & 40 & 25 \\
\hline
\end{tabular}

Tissue MBP is strength of staining of liver biopsy specimens with anti-MBP on a scale $0-3$. See table 1 for liver blood tests units and normal ranges.

PSC = primary sclerosing cholangitis; $\mathrm{PBC}=$ primary biliary cirrhosis; ldo = large duct obstruction.

density of staining increasing with severity of liver disease up to grade 3 with the cirrhotics (fig. 1).

Metastasis: all cases showed MBP staining, but only two of the four had grades 2 or 3 staining (fig. 2).

Biliary disease: mild to moderate staining with anti-MBP (grades 1-3).

Hepatitis: either no staining or only grade 1 .

Miscellaneous: variable MBP staining in liver: the only ones of grades 2 or 3 were a case of fatty change and a cirrhosis (the latter secondary to chronic active hepatitis).

\section{Discussion}

The first conclusions that can be drawn from this study are essentially similar to those of

Table 5 MBP in patients with hepatitis of varied aetiology

\begin{tabular}{|c|c|c|c|c|c|c|c|c|}
\hline $\begin{array}{l}\text { Case } \\
\text { No }\end{array}$ & $\begin{array}{l}\text { Liver biopsy specimen } \\
\text { appearance }\end{array}$ & $\begin{array}{l}\text { Serum } \\
(\mu g / l)\end{array}$ & $\begin{array}{l}\text { Tissue } \\
M B P\end{array}$ & $A S T$ & $A P$ & $G G T$ & Albumin & Bilirubin \\
\hline 36 & Reactive hepatitis & 574 & 0 & 26 & 267 & 67 & 44 & 5 \\
\hline 37 & Reactive hepatitis & 5801 & $0 / 1$ & 21 & 303 & 200 & 42 & 11 \\
\hline 38 & Reactive hepatitis & 1472 & 1 & 50 & 246 & 65 & 50 & 15 \\
\hline 39 & Reactive hepatitis & 5212 & 1 & 15 & 916 & - & 38 & 2 \\
\hline 40 & Reactive hepatitis & 2324 & 1 & 34 & 288 & 94 & 41 & 20 \\
\hline 41 & Reactive hepatitis & 6073 & 1 & 16 & 617 & 111 & 44 & 3 \\
\hline 42 & Reactive hepatitis & 1563 & 1 & 29 & 510 & 75 & 40 & 3 \\
\hline 43 & $\begin{array}{l}\text { Granulomatous } \\
\text { hepatitis }\end{array}$ & 1091 & 0 & 61 & 655 & 279 & 35 & 6 \\
\hline 44 & $\begin{array}{l}\text { Cholestatic hepatitis } \\
\text { ?NANB }\end{array}$ & 275 & 1 & 57 & 784 & 42 & 26 & 206 \\
\hline 45 & Hepatitis ?NANB & 82 & 1 & 21 & 434 & 58 & 43 & 9 \\
\hline 46 & Mild CPH (NANB) & 287 & 1 & 384 & 150 & 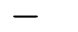 & 43 & 11 \\
\hline
\end{tabular}

Tissue MBP is strength of staining of liver biopsy specimens with anti-MBP on a scale $0-3$. See table 1 for liver blood tests and normal ranges.

$\mathrm{CPH}=$ chronic persistent hepatitis; $\mathrm{NANB}=$ non- $\mathrm{A}$, non-B viral hepatitis (including hepatitis C, et al). our previous study, ${ }^{10}$ with data from 57 more liver biopsy specimens to add to those from the 71 tested previously.

Broadly speaking, the results confirm a number of features relating to the staining pattern for MBP in the liver:

1 Liver biopsy specimens with normal histological features show no significant staining with anti-MBP (13 patients in all now tested).

2 The staining pattern with anti-MBP is generally cytoplasmic and diffuse.

3 Liver biopsy specimens from patients with alcoholic liver disease tend to show staining with anti-MBP, and the degree of staining seems to be related to the severity and duration of the liver damage-those with fatty change tend only to show minor staining (grade 1); those with cirrhosis show strong staining (grade 3 ), with the specimens from patients with alcoholic hepatitis or fibrosis falling short of cirrhosis generally showing moderate (grade 2) staining.

4 Liver biopsy specimens from patients with biliary disease show mild to moderate MBP staining.

5 The miscellaneous hepatitics and others (tables 5 and 6) show generally only mild MBP staining, with only one showing extensive MBP (grade 2/3) staining, a case of cirrhosis secondary to chronic active hepatitis (severe disease).

6 The absence of high serum MBP concentrations and detectable $\mathrm{MBP}$ in the liver does not exclude the presence of clinically relevant liver disease on morphological or biochemical grounds.

The group of biopsy specimens with tumours was smaller than in our first study, ${ }^{10}$ where four of five liver biopsy specimens containing metastatic tumour had shown grade 2 or 3 staining, most noticeable in the tissue adjacent to the tumour. In the current study two showed grade 2 or 3 staining, and two showed only grade 1 . One of these did not contain the tumour within the fresh sample of liver, and thus may not be representativethat is, the much raised MBP concentration in hepatocytes might be only a local effect seen adjacent to the tumour and not a general effect throughout the liver.

The main question which the study set out to investigate was whether there was any association between the amount of MBP in the liver (its site of synthesis), as detectable by immunohistochemistry, and the serum concentration.

There was no obvious correlation between serum and liver MBP concentrations. The correlation coefficient $(-0.076)$ is given in table 7 -virtually random. There is a wide range for serum MBP concentrations in the general population, with $90 \%$ lying between 33-2656 $\mu \mathrm{g} / 1 .{ }^{11}$ In our sample of patients with liver disease, however, 17 of $57(30 \%)$ lay above this "normal" range. Table 8 shows these top 17 arranged in ascending order of serum MBP, and again there was no significant correlation between serum and tissue MBP (correlation coefficient $0 \cdot 268$ ). 
Figure 2 Hepatocytes showing moderate (grade 2) staining with anti$M B P$ on frozen tissue section from patient with metastasis in the liver (tumour not seen in this field).

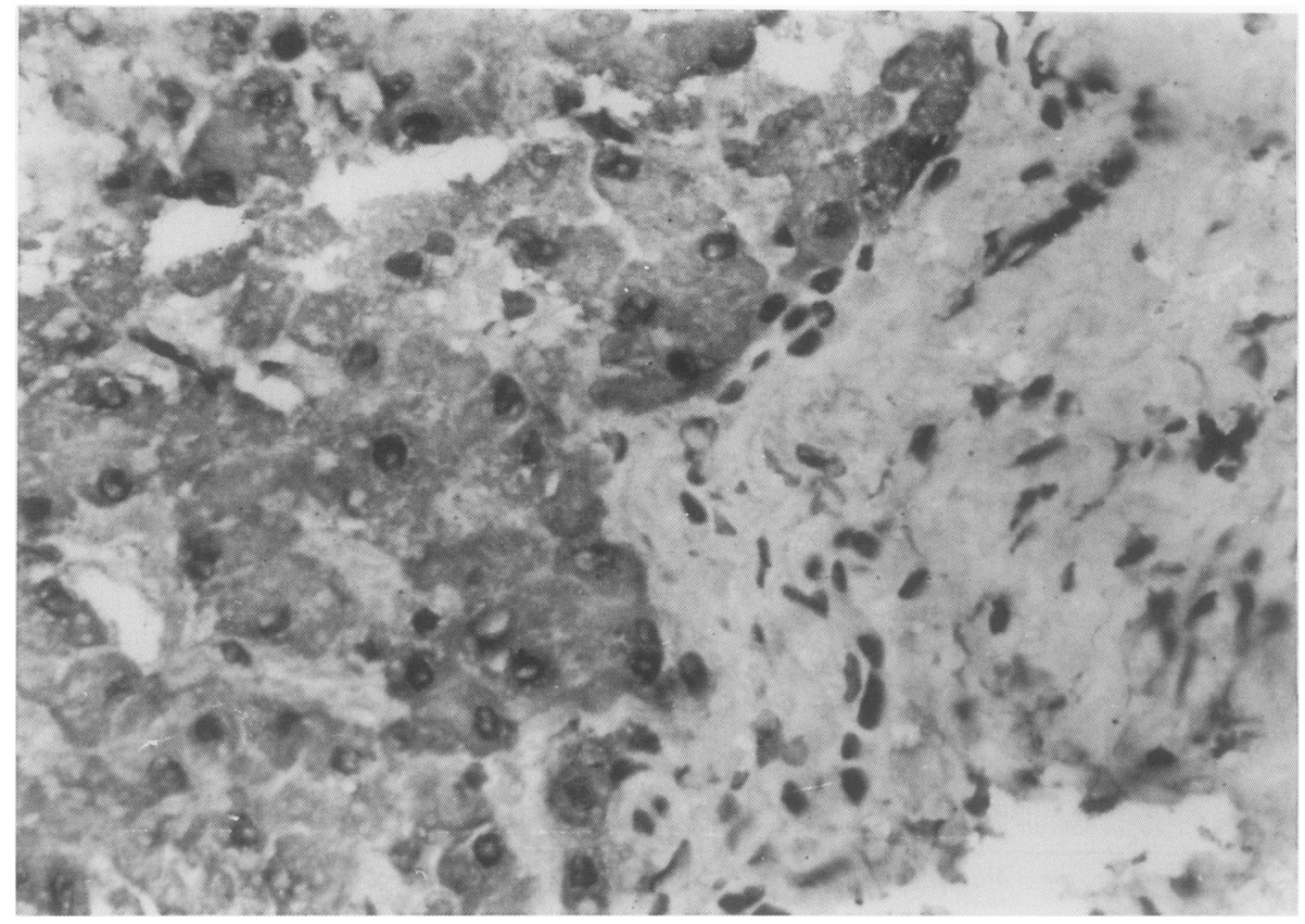

Table 6 MBP in patients with abnormal liver biopsy specimens of varied aetiology

\begin{tabular}{|c|c|c|c|c|c|c|c|c|}
\hline $\begin{array}{l}\text { Case } \\
\text { No }\end{array}$ & $\begin{array}{l}\text { Liver biopsy specimen } \\
\text { appearance }\end{array}$ & $\underset{(\mu g / l)}{\operatorname{Serum}} M B P$ & $\begin{array}{l}\text { Tissue } \\
M B P\end{array}$ & $A S T$ & $A P$ & $G G T$ & Albumin & Bilirubin \\
\hline 47 & Fatty change (Crohn's) & 7160 & 1 & 35 & 418 & 52 & 44 & 11 \\
\hline 48 & Fatty change & 10468 & 2 & 39 & 201 & - & 43 & 30 \\
\hline 49 & Sinusoidal dilatation & 1511 & 1 & 18 & 400 & 247 & 35 & 8 \\
\hline 50 & Mild fibrosis ?drug & 1705 & $0 / 1$ & 50 & 368 & 1035 & 40 & 6 \\
\hline 51 & Mild fibrosis & 900 & 1 & 41 & 459 & - & 41 & 8 \\
\hline 52 & Mild fibrosis & 1643 & 1 & 37 & 344 & 152 & 41 & 15 \\
\hline 53 & Cholestasis (drug) & 2224 & 0 & 48 & 840 & 41 & 43 & 294 \\
\hline 54 & Cholestasis ?drug & 1418 & 1 & 33 & 39 & 189 & 42 & 79 \\
\hline 55 & $\begin{array}{l}\text { Minor abnormalities } \\
\text { (methotrexate) }\end{array}$ & 1133 & 1 & 30 & 156 & - & - & 7 \\
\hline 56 & $\begin{array}{l}\text { Haemochromatosis } \\
\text { with cirrhosis }\end{array}$ & 2385 & 1 & 106 & 413 & - & 25 & 55 \\
\hline 57 & Cirrhosis (CAH) & 201 & $2 / 3$ & 837 & 1118 & 79 & 39 & 161 \\
\hline
\end{tabular}

Tissue MBP is expressed as strength of staining of liver biopsy specimens with anti-MBP on a scale $0-3$. See table 1 for units and normal ranges of liver blood tests.

Drugs (case 50) antiepileptics including phenytoin and phenobarbitone; case 53 unknown drug (took many cardiac/antihypertensive drugs); case 54 azathioprine.

$\mathrm{CAH}=$ chronic active hepatitis

The results for liver blood tests are also included in tables 1-6, these samples being taken on the day of the biopsy. Again there was no significant correlation between any of these figures and the serum or tissue MBP (see table 7 for correlation coefficients).

As the hepatocytes are considered to be the major site of synthesis of MBP, it was rather unexpected to find no correlation between serum concentrations of MBP and staining for MBP in hepatocytes. It would perhaps have been very useful in the clinical assessment of liver disease to find higher concentrations of serum MBP in patients with

Table 7 Spearman rank correlation coefficient between MBP in serum or liver and other recorded variables (possible range $-1 \cdot 0$ to $+1 \cdot 0$ ).

\begin{tabular}{|c|c|c|c|c|c|c|c|}
\hline & $\begin{array}{l}\text { Serum } \\
M B P\end{array}$ & $\begin{array}{l}\text { Tissue } \\
M B P\end{array}$ & $A S T$ & $A P$ & $G G T$ & Albumin & Bilirubin \\
\hline $\begin{array}{l}\text { Serum MBP } \\
\text { Tissue MBP }\end{array}$ & -0.076 & -0.076 & $\begin{array}{r}-0.030 \\
0.385\end{array}$ & $\begin{array}{r}-0.098 \\
0.096\end{array}$ & $\begin{array}{l}0.052 \\
0.290\end{array}$ & $\begin{array}{r}0.119 \\
-0.318\end{array}$ & $\begin{array}{l}0.020 \\
0 \cdot 260\end{array}$ \\
\hline
\end{tabular}

increased MBP detectable in the liver (which in turn appears to be related to severity of liver damage in certain clinical settings). As it is, the correlation coefficient is virtually 0 . However, with there being such a wide "normal" range for serum MBP concentrations, and with there being no way of determining the concentration of MBP in the serum before the onset of liver disease, it is always possible that those patients with high intensity of staining in the liver for MBP had in fact also shown a substantial proportionate increase in serum MBP from the level prior to the onset of disease, but that this new level was still within the "normal" range. To investigate this would require measurement of serum MBP perhaps several years before a biopsy specimen was taken as a base-line level, which would obviously be impossible unless MBP was widely measured on a routine basis, which is unlikely for the foreseeable future.

This lack of correlation between blood concentrations and apparent tissue presence of a compound is not unprecedented when considering synthesis and release of substances from cells. In endocrine cells and tumours it is well known that there is not always a direct correlation between what is found in the serum and what is detectable in the cells of origin. In a study of 95 patients with insulinoma (an endocrine tumour of pancreatic islet cells), all of whom had documented hyperinsulinaemia, tumour cells uniformly stained weaker for insulin than corresponding normal cells in the same pancreas, and in a few cases insulin was not detectable at all by immunohistochemistry. ${ }^{12}$ Conversely, in the liver patients with $a$-1-antrypsin deficiency in the serum have large amounts of it in the liver. ${ }^{13}$

These examples may not be directly com- 
Table 8 Patients with serum MBP outside range 33-2656 $\mu \mathrm{g} / \mathrm{l}$ arranged in ascending order of serum $M B P$, and liver MBP included for comparison

\begin{tabular}{llcl}
\hline $\begin{array}{l}\text { Case } \\
\text { No }\end{array}$ & Histology & $\begin{array}{c}\text { Serum } \\
M B P\end{array}$ & $\begin{array}{l}\text { Tissue } \\
M B P\end{array}$ \\
\hline 4 & Fatty (ALD) & 2832 & $0 / 1$ \\
18 & Hepatitis/fibrosis (ALD) & 3021 & $2 / 3$ \\
11 & Hepatitis (ALD) & 3407 & $1 / 2$ \\
28 & Metastasis & 4235 & 1 \\
2 & Normal & 4532 & $0 / 1$ \\
17 & Hepatitis/fibrosis (ALD) & 4532 & 2 \\
29 & Metastasis & 4804 & 2 \\
39 & Reactive hepatitis & 5212 & 1 \\
37 & Reactive hepatitis & 5801 & $0 / 1$ \\
41 & Reactive hepatitis & 6073 & 1 \\
10 & Hepatitis (ALD) & 6122 & $1 / 2$ \\
47 & Fatty (Crohn's) & 7160 & 1 \\
22 & Cirrhosis (ALD) & 7558 & 2 \\
33 & PBC 2 & 10113 & 2 \\
48 & Fatty change & 10468 & 2 \\
15 & Hepatitis/fibrosis (ALD) & 13197 & 2 \\
14 & Hepatitis/fibrosis (ALD) & 17306 & $1 / 2$ \\
\hline
\end{tabular}

Spearman rank correlation coefficient $=\mathbf{0} \cdot 268$. $\mathrm{ALD}=$ alcoholic liver disease

parable with the present situation, but abnormalities in storage capacity (as in endocrine tumours), or structural variations in the secreted product (as for $a$-1-antitrypsin), among others, could be relevant.

In conclusion, there does seem to be an association between pathological changes in the liver and staining for MBP, most pronounced in alcoholic liver disease where there seems to be a direct correlation between the severity of the damage and detectable MBP. A greater proportion of patients with liver disease have raised serum MBP concentrations compared with the general population, but this does not correlate with either the severity of the hepatic disease or the amount of MBP detectable in the liver by immunohistochem- istry. And finally, there was no significant correlation between MBP in serum or liver and other tests of liver function or damage.

1 Kawasaki T, Etoh R, Yamashina I. Isolation and characterisation of a mannose-binding protein from rabbit liver. Biochem Biophys Res Commun 1978;81:1018-24.

2 Kozutsumi Y, Kawasaki T, Yamashina I. Kinetical properties of the serum mannan-binding protein from rabbit. A comparison with those of the liver mannan-binding protein. $\mathcal{F}$ Biochem 1981;90:1799-807.

3 Kawasaki N, Kawasaki T, Yamashina I. Isolation and characterisation of a mannose-binding protein from human serum. 7 Biochem 1983;94:937-47.

4 Kawasaki N, Kawasaki T, Yamashina I. Mannan-binding protein and conglutinin in bovine serum. $\mathcal{F}$ Biochem 1985;98:1309-20.

5 Oka S, Ikeda K, Kawasaki T, Yamashina I. Isolation and characterization of two distinct mannan-binding proteins from rat serum. Arch Biochem Biophys 1988;260:257-66

6 Super M, Thiel S, Lu J, Levinsky RJ, Turner MW. Association of low levels of mannan-binding protein with a common defect of opsonisation. Lancet 1989;ii: 1236-9.

7 Kuhlman M, Joiner K, Ezekowitz RAB. The human mannose-binding protein functions as an opsonin. $\mathcal{F}$ Exp Med 1989;169:1733-45.

8 Ezekowitz RAB, Kuhlman M, Groopman J, Byrn R. A human serum mannose-binding protein inhibits in vitro infection by the human immunodeficiency virus. $\mathcal{F} \operatorname{Exp}_{p}$ Med 1989;169:185-96.

9 Ezekowitz RAB, Day LE, Herman GE. A human mannose-binding protein is an acute-phase reactant that shares sequence homology with other vertebrate lectins. f Exp Med 1988;167:1034-46.

10 Ryley NG, Heryet AR, Lu J, Reid KBM, Fleming KA Mannan-binding protein in human liver. 7 Immunol Methods 1991;141:73-9.

$11 \mathrm{Lu} \mathrm{J}$, Thiel S, Wiedemann H, Timpl R, Reid KBM Binding of the pentamer/hexamer forms of mannanbinding of the pentamer/hexamer forms of mannan$\mathrm{C}_{1} \mathrm{r}_{2} \mathrm{Cls}_{2}$ complex of the classical pathway of complement, without involvement of Clq. $f$ Immunol ment, without in

12 Liu T-H, Tseng H-C, Zhu Y, Zhong S-X, Chen J, Cui Q-C. Insulinoma-an immunocytochemical and morphologic analysis of 95 cases. Cancer 1985;56: $1420-9$.

13 Ishak KG, Sharp HL. Metabolic errors and liver disease. In: MacSween RNM, Anthony PP, Scheuer PJ, eds., Pathology of the liver. Edinburgh: Churchill Livingstone, 1987:118-23. 